\title{
Assessment of Yield Loss in Maize due to Attack by the Maize Borer, Chilo partellus (Swinhoe)
}

\author{
Prem Nidhi Sharma ${ }^{1}$ and Purushottam Gautam ${ }^{2}$ \\ ${ }^{1}$ Nepal Agricultural Research Council, Khumaltar, Lalitpur \\ ${ }^{2}$ National Wheat Research Program, Bhairahawa, Rupandehi
}

\begin{abstract}
The maize borer, Chilo partellus (Swinhoe), is one of the major biotic constrains reducing maize productivity in Nepal. Summer maize is infested mainly by it rather than by other insect species in Nepal. National Maize Research Program (NMRP)-Rampur farm was considered as a potential spot for this study where summer maize is highly infested every year by this pest. This study was conducted during the summers of 2004 and 2005 with an objective of assessing the loss by it in maize. A maize variety, Arun-2, was used in this study. Yield loss by this pest was estimated by obtaining the yield difference between the chemically protected and unprotected maize plants. Number of plant stands, number of stem breakage, number of ears harvested, number of poor cobs, 1000 grain weight, and stem tunneling were also recorded as the yield affecting factors. The yield difference was significantly less (by $28 \%$ ) in unprotected maize as compared to protected maize. Number of plant stands, number of ears harvested and 1000 grain weight were found less (by 8.5, 14, and 6\%, respectively) whereas number of stem breakage, number of poor cobs, length of tunnels per plant and per tunnel length were found higher (by 16, 6, 30, and 24\%, respectively) in unprotected maize. This study has suggested that application of plant protection measures against C. patellus can significantly increase maize productivity and hence can greatly contribute in poverty alleviation in Nepal.
\end{abstract}

Key words: maize borer, Chilo partellus, yield loss assessment, maize

\section{Introduction}

Maize (Zea mays L.) is the second major food crop after rice in Nepal. It is grown in summer season in mid-hills and high-hill whereas in Terai and Inner Terai regions it can be grown throughout the year as summer, winter, and spring maize. Among the several major insect pests of maize, the maize borer, Chilo partellus (Swinhoe) is the most destructive one causing heavy yield loss in maize. Summer and winter maize are reported to be damaged whereas winter maize is undamaged by this pest (Coppel et al. 1985, Sharma et al. 2010). Foliage damage, stem tunneling, dead-heart, stem breakage, plant lodging, ear damage, and tassel damage are the various damages caused by this pest. Foliage damage, stem tunneling and dead heart are, however, the major ones that cause severe yield loss in maize (Chatterji et al. 1969, Attri et al. 1968, Mathur et al. 1981). To get information on maize yield loss caused by this pest, it is an essential prerequisite for both the farmers and maize entomologists to take any decisive action towards managing it in maize protection. This study provides the estimates of maize yield loss caused by $C$. partellus and elucidates the effect of its damage on various yield affecting factors.

\section{Methodology \\ NMRP-Rampur farm was considered as a potential spot to this study where the summer maize is highly infested every year by this pest. This study was conducted during the summers of 2004 and 2005. A maize variety, Arun-2, was used in this study. Planting was done on the last week of May; and harvesting was at second week of August. Fertilizers were applied @ 120:60:40 kg NPK/ha. There were two treatments -}


chemically protected and unprotected maize plants arranged in a randomized complete block design replicating two times in the first year and five times in the second year. Yield loss was estimated by obtaining the yield difference between the chemically protected and unprotected maize plants. In the chemically protected treatment, maize plants were treated by two applications of Furadon (carbofuran 3\% granules @ $10 \mathrm{~kg} / \mathrm{ha}$ ) in the maize whorls: first at 25 days and second at 40 days after planting. No insecticide was applied in the control (check) maize plants. Every plot was of 2 rows of $5 \mathrm{~m}$ length with plant to plant spacing of $25 \mathrm{~cm}$ and row to row spacing of $75 \mathrm{~cm}$. There were two boarder rows in between every protected and unprotected maize plot. No insecticide was applied in the border rows. Agronomical practices were as per NMRP recommendations.

Grain yield and 1000 grain weight were taken when the moisture level in the grains was below $14 \%$ after sun drying. Number of plant stands, number of stem breakage, number of ears harvested, number of poor cobs and stem tunneling were also recorded as the yield affecting factors during and after the harvesting. Number of tunnels per plant, length of tunnels per plant and length of individual tunnel were recorded from at least 10 randomly selected plants per plot by splitting maize stalks along from the root base to ear base. Data were summarized separately for 2004 and 2005 and the combined data of both the years were analyzed statistically with MSTATC.

Table 1. Comparison of yield and yield affecting factors for chemically protected and unprotected maize plants to maize borer

\begin{tabular}{|c|c|c|c|c|c|c|}
\hline & $\begin{array}{l}\text { No of plant } \\
\text { stands }\left(\mathrm{ha}^{-1}\right)\end{array}$ & $\begin{array}{l}\text { No of stemb } \\
\text { reakage }\left(\mathrm{ha}^{-1}\right)\end{array}$ & $\begin{array}{l}\text { No of ear sha } \\
\text { rvested }\left(\text { ha }^{-1}\right)\end{array}$ & $\begin{array}{l}\text { No of poor } \\
\text { cobs }\left(h^{-1}\right)\end{array}$ & $\begin{array}{l}1000 \text { grain } \\
\text { weight(g) }\end{array}$ & $\begin{array}{l}\text { Yield } \\
\text { (kg/ha) }\end{array}$ \\
\hline \multicolumn{7}{|l|}{ Summer 2004} \\
\hline Protected maize & 51333.3 & 7333.3 & 36666.7 & 9333.3 & 213.5 & 1521.0 \\
\hline Unprotected maize & 39333.3 & 10666.7 & 28000 & 6666.7 & 206.5 & 1068 \\
\hline $\begin{array}{l}\% \text { decreased or } \\
\text { increased in } \\
\text { unprotected } \\
\text { maize }\end{array}$ & $23.4 \triangle$ & $45.5 \triangle$ & $23.6 \nabla$ & $28.6 \nabla$ & $3.3 \nabla$ & $29.8 \nabla$ \\
\hline \multicolumn{7}{|l|}{ Summer 2005} \\
\hline Protected maize & 38400.0 & 5066.7 & 33333.3 & 5866.7 & 229.94 & 1369.07 \\
\hline Unprotected maize & 38133.3 & 5066.7 & 30133.3 & 7466.7 & 214.42 & 998.4 \\
\hline $\begin{array}{l}\% \text { decreased or } \\
\text { increased in } \\
\text { unprotected maize }\end{array}$ & $0.7 \nabla$ & 0 & $9.6 \nabla$ & $27.3 \triangle$ & $6.7 \nabla$ & $27.1 \nabla$ \\
\hline \multicolumn{7}{|l|}{$\begin{array}{l}\text { Summers } 2004 \\
\text { and } 2005 \text { combined }\end{array}$} \\
\hline Protected maize & 42133.3 & 5733.3 & 34266.7 & 6800 & 225.2 & 1412.4 \\
\hline Unprotected maize & 38533.3 & 6666.7 & 29466.7 & 7200 & 212.2 & 1018.3 \\
\hline F-test & & ns & ns & ns & ns & $\star \star$ \\
\hline CV\% & 12.87 & 52.55 & 17.39 & 44.8 & 7.17 & 14.76 \\
\hline $\begin{array}{l}\% \text { decreased or } \\
\text { increased } \\
\text { inunprotectedmaize }\end{array}$ & $8.5 \nabla$ & $16.3 \triangle$ & $14 \nabla$ & $5.9 \triangle$ & $5.8 \nabla$ & $27.9 \nabla$ \\
\hline
\end{tabular}




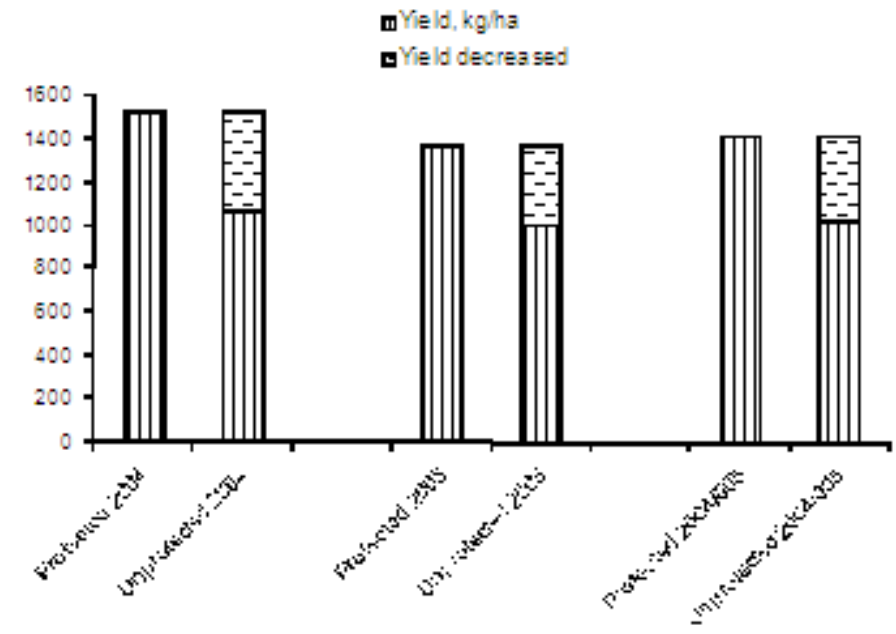

Fig. 1. Comparison of yields for chemically protected and unprotected maize plants to maize borer

Table 2. Comparison of stem tunneling for chemically protected and unprotected maize plants to maize borer

\begin{tabular}{|c|c|c|c|}
\hline & $\begin{array}{l}\text { No of } \\
\text { tunnels/plant }\end{array}$ & $\begin{array}{l}\text { Length of } \\
\text { tunnels/plant (cm) }\end{array}$ & $\begin{array}{l}\text { Per tunnel } \\
\text { length }(\mathrm{cm})\end{array}$ \\
\hline \multicolumn{4}{|l|}{ Summer 2004} \\
\hline $\begin{array}{l}\text { Protected maize } \\
\text { Unprotected maize }\end{array}$ & $\begin{array}{l}1.75 \\
2.65\end{array}$ & $\begin{array}{l}14.55 \\
33.25\end{array}$ & $\begin{array}{l}8.28 \\
12.85\end{array}$ \\
\hline $\begin{array}{l}\text { \% decreased or } \\
\text { increased } \\
\text { inunprotectedmaize } \\
\text { Summer } 2005\end{array}$ & $51.41 \triangle$ & $128.5 \triangle$ & $55.2 \triangle$ \\
\hline $\begin{array}{l}\text { Protected maize } \\
\text { Unprotected maize }\end{array}$ & $\begin{array}{l}1.8 \\
1.5\end{array}$ & 15.2 & $\begin{array}{l}8.4 \\
9.5\end{array}$ \\
\hline $\begin{array}{l}\% \text { decreased or } \\
\text { increased in } \\
\text { unprotected } \\
\text { maize }\end{array}$ & $15.8 \nabla$ & $7.6 \nabla$ & $12.4 \triangle$ \\
\hline \multicolumn{4}{|l|}{$\begin{array}{l}\text { Summers } 2004 \\
\text { and } 2005 \text { combined }\end{array}$} \\
\hline Protected maize & 1.8 & 15.0 & 8.4 \\
\hline Unprotected maize & 1.8 & 19.5 & 10.4 \\
\hline F-test & ns & ns & ns \\
\hline LSD & 0.783 & 10.713 & 3.131 \\
\hline $\begin{array}{l}\% \text { decreased or } \\
\text { increased in } \\
\text { unprotected } \\
\text { maize }\end{array}$ & 0 & $30 \triangle$ & $23.8 \triangle$ \\
\hline
\end{tabular}




\section{Results and Discussion}

Yield and yield affecting factors were compared for chemically protected and unprotected maize plants (Table 1, Figure 1). Maize yield was decreased by 27.1 to $29.8 \%$ (998.07 kg to $1068 \mathrm{~kg} / \mathrm{ha}$ ) in unprotected maize as compared to protected maize (1369.07kg to $1521 \mathrm{~kg} /$ ha) when the data for 2004 and 2005 were compared separately. When the data for 2004 and 2005 were combined and analyzed, yield in unprotected plots was significantly different (less by 27.9\%: $1018.3 \mathrm{~kg} / \mathrm{ha}$ ) when compared to protected maize (1412.4kg/ha). Number of plant stands, number of ears harvested and 1000 grain weight were decreased in unprotected maize during both the years (by 0.7 to 23.4, 9.6 to 23.6 and 3.3 to $6.7 \%$, respectively), whereas number of stem breakage and number of poor cobs were increased in unprotected maize by 16.3 and $5.9 \%$, respectively (see combined data for 2004 and 2005). However, none of the yield affecting factors in unprotected maize was significantly different from the protected maize. Length of tunnels per plant and per tunnel length were increased in unprotected maize by 30 and $23.8 \%$ respectively (see combined data for 2004 and 2005); these data were statistically non-significant (Table 2).

In maize the yield and yield affecting factors clearly showed that $C$. partellus infestation was higher during the summer of 2004 than the summer of 2005 (Table 1). In our previous study (Sharma et al. 2010) we reported that there was maximum foliage damage and high stem tunneling in summer maize of 2004. But in summer maize of 2005, there was very low foliage damage but interestingly high stem tunneling was observed. It could probably be due to the unfavorable environmental effect on the insect activity during the summer of 2005. There was very low rainfall, dry and very hot condition during that period that could have lead the insect to feed inside the stem rather than feeding on whorl leaves. High stem tunneling and more foliage damage should have caused higher yield decrease in 2004.

Arun-2 was relatively tolerant/moderately resistant genotype to C. partellus in our previous study (Sharma et al. 2010, 2007). We observed 27 to 30\% yield decrease in unprotected maize using this variety in this study. We conclude from this and previous studies that yield loss could be increased very high if a susceptible maize genotype was used. This is our first study for yield loss assessment in maize due to this pest in Nepal. Yield loss from this pest has been reported to be 24 to $83 \%$ in other countries by this pest (Chatterji et al. 1969, Attri et al. 1968, Mathur et al. 1981). In this study, Arun-2 showed low range of yield loss which might be due to its high tolerance level against this pest.

Maize productivity is greatly reduced by various biotic and abiotic stresses. C. partellus is one of the major biotic stresses reducing maize productivity in Nepal. Increasing maize productivity by controlling this pest has been a primary need to Nepalese farmers and Nepal Government to alleviate poverty level in the country. This pest has been a great challenge to maize entomologists and agriculturists in maize protection in Nepal. Entomologists need to focus their research with top priority against this pest in maize protection. The integrated pest management (IPM) approach which is sustainable and eco-friendly, should be employed against this pest to increase maize productivity in Nepal. Use of maize borer tolerant cultivars is the best approach in controlling this pest which is ecofriendly and sustainable approach in maize protection. Other control approaches such as biological, cultural and judicious use of chemicals are equally important against this pest.

\section{Acknowledgements}

SDC and CIMMYT are greatly acknowledged for funding this project. Due thanks go to Prof. Dr. F.P Neupane, Academician, NAST, for his encouragement to this work and kindly helping in finding references to this paper and editing it. We thank Mr. Baburam Pande, Technical Officer, NMRP, Rampur, for his help in statistical analysis of the data. We also thank Mr. Lil Bahadur B.K., NMRP, Rampur, for his sincere and regular field assistance during the study period.

\section{References}

Attri, B.S. and P.L. Sharma. 1968. Percentage infestation by Chilo zonellus (Swinhoe) to maize at different elevation in Himachal Pradesh. Indian Journal of Entomology 30(4):317-318.

Chatterji, S.M., W.R. Young, G..C. Sharma, I.V. Sayi, B.S. Chahal, B.P. Khare, Y.S. Rathore, V.P.S. Panwar and K.H. Siddiqui. 1969. Estimation of loss in yield of maize due to insect pests with special reference 
Prem Nidhi Sharma \& Purushottam Gautam'Assessment of Yield

to borers. Indian Journal of Entomology 31:109-115.

Coppel, H.C., R.K. Chapman and F.P. Neupane. 1985. Monitoring the maize borer, Chilo partellus (Swinhoe) in Nepal through light trap and life table studies. Nepalese Journal of Agriculture 16:85-92.

Mathur, L.M.L. and H.S. Rawat. 1981. Studies on maize pests with certain observations on the survival of the hibernating larvae of Chilo partellus (Swinhoe) and its incidence in relation to sowing date. Rajasthan Journal of Pesticides 8:17-31.
Sharma, P.N., R.B. Thapa, P. Gautam, Y.P. Giri, H.P. Pathak and S. Aryal. 2007. Resistance screening of promising maize genotypes against maize stem borer, Chilo partellus Swinhoe. In: Proceedings of the $25^{\text {th }}$ National Summer Crops Research Workshop on Maize Research and Production in Nepal. NMRP, Rampur, Chitwan. pp. 278-280.

Sharma, P.N., R.B. Thapa, P. Gautam, and Y.P. Giri. 2010. Assessment of stem borer (Chilo partellus Swinhoe) severity in summer, winter and spring maize. Paper presented at $26^{\text {th }}$ National Summer Crops Research Workshop held at National Maize Research Program, Rampur, Chitwan, Nepal. February 19-21, 2010. 
Nepal Journal of Science and Technology 11 (2010) 25-30 